\title{
Understanding Death and Grief in the Context of Pandemics - Challenges and Support in Response to COVID-19
}

DOI: 10.19181/inter.2020.12.4.4

Ссылка для цитирования:

Фанг Ч. Понимание смерти и горя в контексте пандемий - вызовы и поддержка в ответ на COVID-19 // Интеракция. Интервью. Интерпретация. 2020. T. 12. № 4. C. 46-52. DOI: https://doi. org/10.19181/inter.2020.12.4.4

For citation:

Fang C. (2020) Understanding Death and Grief in the Context of Pandemics - Challenges and Support in Response to COVID-19. Interaction. Interview. Interpretation. Vol. 12. No. 4. P. 46-52. DOI: https://doi.org/10.19181/inter.2020.12.4.4

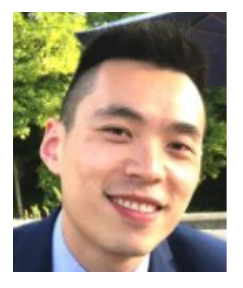

Chao Fang *

This article presents a preliminary inquiry into the impacts of COVID-19 on death, dying and bereavement. Adopting a sociological lens, this inquiry explores how social norms and values have shaped and been shaped by experiences of loss and grief amid COVID-19 outbreak. By examining relevant media and academic discourses, the author critically analyses the challenges confronted by those experiencing dying and grieving during this pandemic, and further envisages needs for better bereavement support moving forward. It finds that both individuals and collectives express diverse needs in response to COVID-19 related loss and grief. This highlights grief as a process of meaning-making, emphasising the importance of timely, holistic and continuous support. Further, the significance of socio-cultural environments also become evident. Ultimately, this article explores avenues for further developing bereavement support.

Keywords: COVID-19; pandemic; bad death; grief; bereavement support bath.ac.uk.

* Fang Chao - PhD, Researcher in the Centre for Death and Society, University of Bath, UK, cf493@ 


\section{Introduction}

The COVID-19 pandemic has claimed a significant number of lives worldwide. Many countries and regions have introduced strict social restrictions and/or lockdown measures to combat the virus outbreak. In the face of unprecedented challenges and uncertainties around loss, anxiety and social isolation, it is of particular importance to understand death and grief, and subsequently to guide timely support and appropriate responses to those who may be affected. As widely reported by media outlets, many people have lost their lives often in suffering, isolation and unexpectedly, as a result of the COVID-19 outbreak. Despite the nature of these individual deaths being "bad", the idealisation of death can also be seen at a collective level. As such, how to respond to these deaths in the context of COVID-19 is not only an individual task but also a societal matter, requiring rigorous approaches for both individuals and society when seeking support to face and deal with loss and grief.

\section{Bad and good deaths during COVID-19}

Death and dying during the COVID-19 pandemic can be deeply distressing and often undignified, causing not only severe physical damage and mental distress to individuals but also disorder and dysfunction to society. The unprecedented levels of control and restriction imposed onto individuals by the authorities could further undermine people's autonomy and the resources available to them. Such experiences are likely to violate predominant public and healthcare discourses about "good death" for individuals, which favours a pain-free and smooth dying process emphasising holistic wellbeing, family presence, autonomy and dignity (Meier et al., 2017).

Three types of bad deaths have been seen in this pandemic: painful, lonely and unexpected deaths. A painful death refers to a distressing process in which patients with the virus die with extensive physical deteriorations, discomforts and shortness of breath. Painful of this nature can be further escalated by forced separation between patients and their loved ones as a result of the strict prevention and control measures. The Telegraph in the United Kingdom, in which a victim "cried out for his family before dying alone, has recorded a tragic story". Death in this manner is essentially a lonely death, which may be broadly representative of the dying experience that many patients with COVID-19 and/or other terminal conditions may suffer. Lonely death is not only dying whilst physically alone but may also be the result from social isolation and inequalities (Seale, 2004). People from low-income backgrounds and ethnic minority groups have also been reportedly the worst hit communities by COVID-19 related deaths, questioning social responses and broader structures in the context of the pandemic (Bear et al.,

${ }^{1}$ Ward V. (2020) Coronavirus Survivor Describes Tragedy of Patient Who Cried out for His Family before Dying Alone. The Telegraph. URL: https://www.telegraph.co.uk/news/2020/04/07/coronanvirus-survivor-describes-tragedy-patient-cried-family/ (accessed 1 August 2020). 
2020). Furthermore, deaths linked to COVID-19 can be sudden and unexpected, thus challenging and shocking to those left behind. The unexpectedness is even more evident in the face of premature deaths, with the youngest victim to date aged only six weeks old ${ }^{2}$. Child deaths are often considered untimely, unnatural therefore particularly bad, likely leaving the bereaved family and broader society struggling to justify the loss.

Despite "bad" deaths prevailing in these pandemic, "good" deaths have also been socially constructed. Heroic deaths have been constructed and promoted by media and public discourses during this pandemic, to honour healthcare and other essential workers (Atlani-Duault et al., 2020). The sacrifices of many other key contributors, who have lost their lives to save and help others, have also been honoured in their respective countries. The recognition of their professional identity and selfless spirit can offer meaningful reminders of hope and wholeness to society as an entity (Goren, 2007). As such, heroisation of deaths is a collective strategy to provide meaningful scripts to support individual losses and to reinforce social solidarity (Bennett, 2004).

\section{Challenges and needs in facing grief and bereavement}

Following the mass deaths seen during COVID-19, both individuals and society will inevitably confront a changed world without a loved one and a valuable member. During the difficult time of facing the loss of a loved one, whilst experiencing significant social constraints, bereaved people may find their needs for processing the emotional tensions associated with grief largely unattended. Thus, they may encounter difficulties when trying to make sense of their loss. The lockdown and social distancing rules imposed during COVID-19 have strongly suppressed individual autonomy. For bereaved people, even grieving for their loved one with others and through ceremonies may be difficult or impossible. Therefore, they may experience "unresolved grief". From a sociological perspective, the meaning-making process for loss is disabled or disrupted by external restrictions during COVID-19. This sense of helplessness and meaninglessness in the face of loss is also associated with disenfranchised grief, for those whose loss and grief are not publicly acknowledged and thus little supported (Doka, 1989). Not only family members but also other social members, such as healthcare workers, are at risk of being denied the opportunity to grieve. Such disenfranchised grief, in the context of COVID-19, may be experienced distinctively by different people as a result of social neglects and suppressed individual autonomy under control measures.

Furthermore, the expression of grief is also needed by society to deal with mass deaths and crises in the face of this pandemic. Collective responses, such

${ }^{2}$ Sibthorpe C. (2020) Coronavirus: Newborn Baby Becomes "World's Youngest COVID-19 Victim". Sky News. URL: https://news.sky.com/story/coronavirus-newborn-baby-becomes-worlds-youngest-covid-19-victim-11967230 (accessed 1 August 2020). 
as national mourning in China, have been seen as a strategy to ease tensions of social traumas (Alexander, 2004). These collective responses are essentially a grieving process, assembling social members to face destruction and impairment and to reaffirm their conformity to society as an orderly and functional state. Collective grieving may sometimes become difficult and even impossible due to societies lacking the appropriate resources and structures to support these actions. As such, it is essential to ensure available channels for both society as a whole and its members to restore meanings and an equilibrium in a collective and symbolic sense.

\section{Bereavement support in response to COVID-19}

When cities are locked down and travel restrictions are enforced, it is greatly important to support bereaved people who may have to face their loss alone. At this difficult time, compounded with isolation and suppressed individual autonomy, it has become essential to continuously provide support and empower bereaved people to use available resources. Charities, governmental bodies, care providers and local communities have assembled a range of support resources, such as guidelines and hotlines, to provide bereaved people with useful language for dealing with their grief and bereavement. In addition to ensuring resources are available for bereaved people with different needs and from various backgrounds, it is particularly vital at this time to develop a more sympathetic and reciprocal environment. This would enable and motivate bereaved people to facilitate grieving and better make sense of loss. Good bereavement support also requires a wider scope of follow-up assistance post the outbreak. Given the largely "bad" nature of deaths during COVID-19, these bereaved people may have trouble in adjusting to loss in their ongoing lives (Valentine, 2009). It is important to ensure professional care, such as psychotherapy and medical treatments, are available where needed. Meanwhile, not all bereaved people will experience so-called complicated, abnormal or prolonged grief. Instead, bereaved people tend to show resilient responses, to keep functioning and carrying on with their lives in the face of loss, even if this loss is highly difficult to make sense of (Fang, 2020). Therefore, taking a more dynamic and interactive approach to bereavement support is important post the COVID-19 outbreak. This approach could enable bereaved people to not only rely on psychological and clinical frameworks but also draw upon other socially accessible tools, such as language, arts and other creative means, to reconstruct meaning in their ongoing lives (Walter, 1996).

Support is also needed to face and remember mass deaths and shared traumas in ongoing society. Collective grieving activities can often enable publicly acceptable emotions to recognise and integrate loss and crisis into the values and identities of society. Such activities are not necessarily temporary but can be repeated in relation to special tempo-spatial elements, such as annual 
remembrances for the 9-11 terrorist attacks in New York. Similarly, significant locations and dates may be hallowed after the COVID-19 pandemic to collectively and continuously reconstruct the past and to reinforce a communal sense of belonging for the future of society. Therefore, how to manage and transform these symbols can play significant roles in reshaping the emotions of individual bereaved people and the public. Thus, allowing them to further negotiate and contest meanings for themselves as well as society as a whole. Such visible symbols may appear following the outbreak, presenting both opportunities and challenges for governments and communities to transform the collective pain and public emotions into a meaningful shared memory of social solidarity and collective confidence.

\section{Conclusion}

Based on the above discussion, two primary findings become evident. These are, that both individuals and collectives have diverse needs in response to deaths and losses as part of the meaning-making process and that socio-cultural environments play a significant role in this process. How to respond better to these fundamental needs is closely associated with the social environments in which they are situated. As such, better support for grief and bereavement requires a grief literate environment, to allow for mutual understanding and interdependent support both in individual bereaved people's day-to-day settings as well as in broader society (Breen et al., 2020). Based on a wider framework of compassionate communities, the emphasis on "grief literate" environments lies in the empowerment of communities in response to increasing professionalisation and inequalities in bereavement support (Kellehear, 2005).

To create a grief literate environment at different levels would require a rigorous approach during and post the COVID-19 outbreak. Local communities should continuously play a significant role in developing relevant resources and structures to better seek and negotiate appropriate means for dealing with loss. Further, a more inclusive and individualised approach is needed to develop community-based support, responding more directly to the diverse values of grief and bereavement for individuals from different social, religious, ethical, age and gender groups. Self-help groups in a non-psychotherapeutic setting could provide an invaluable model for mutual understanding and support among bereaved people with similar backgrounds and experiences. This model could also enable more context-specific grief literacy in wider compassionate communities and society. Meanwhile, support and guidance from both the public and professional resources, such as the government, social and health care professionals, are also indispensable. These more formalised support frameworks could complement and reinforce community-based support. This cooperation would allow for a "new" structure of bereavement support to form and grow in the changed world following COVID-19. 


\title{
References
}

Alexander J. C. et al. (2004) Cultural Trauma and Collective Identity. Berkeley: University of California Press. DOI: https://doi.org/10.1525/california/9780520235946.001.0001

Atlani-Duault L. et al. (2020) Tracking Online Heroisation and Blame in Epidemics. The Lancet Public Health. Vol. 5. No. 3. P. e137-e138. DOI: https://doi.org/10.1016/s2468-2667(20)30033-5

Bennett S. (2004) Psychoanalytic Reflections on Heroism in a Time of Fallen Heroes. Journal of Nervous and Mental Disease. Vol. 192. No. 3. P. 171-177. DOI: https://doi.org/10.1097/01.nmd.0000116530.23640.a3

Breen L. et al. (2020) Grief Literacy: A Call to Action for Compassionate Communities. Death Studies. DOI: https://doi.org/10.1080/07481187.2020.1739780

Bear L. et al. (2020)"A Good Death" during the Covid-19 Pandemic in the UK: a Report on Key Findings and Recommendations. L.: London School of Economics and Political Science. URL: http://eprints.Ise. ac.uk/id/eprint/10414 (accessed 1 August 2020).

Doka K. J. (1989) Disenfranchised Grief: Recognizing Hidden Sorrow. Lexington: Lexington Books.

Fang C. (2020) Dynamics of Chinese Shidu Parents' Vulnerability in Old Age - A Qualitative Study. Journal of Population Ageing. DOI: https://doi.org/10.1007/s12062-020-09293-4

Goren E. (2007) Society's Use of the Hero Following a National Trauma. American Journal of Psychoanalysis. Vol. 67. P. 37-52. DOI: https://doi.org/10.1057/palgrave.ajp.3350013

Kellehear A. (2005) Compassionate Cities: Public Health and End of Life Care. L.: Routledge.

Meier E. A. et al. (2017) Defining a Good Death (Successful Dying): Literature Review and a Call for Research and Public Dialogue. American Journal of Geriatric Psychiatry. Vol. 24. No. 4. P. 261-271. DOI: https://doi.org/10.1016/j.jagp.2016.01.135

Seale C. (2004) Media Constructions of Dying Alone: a Form of "Bad Death". Social Science \& Medicine. Vol. 58. No. 5. P. 967-974. DOI: https://doi.org/10.1016/j.socscimed.2003.10.038

Valentine C. (2009) Negotiating a Loved One's Dying in Contemporary Japanese Society. Mortality. Vol. 14. No. 1. P. 34-52. DOI: https://doi.org/10.1080/13576270802591269

Walter T. (1996) A New Model of Grief: Bereavement and Biography. Mortality. Vol. 1. No. 1. P. 7-25. DOI: https://doi.org/10.1080/713685822

Received: 06.10.2020

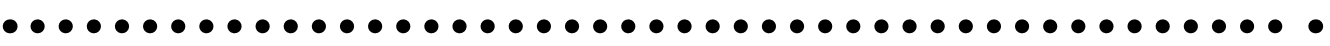

\section{Понимание смерти и горя в контексте пандемий - вызовы и поддержка в ответ на COVID-19}

\author{
DOI: 10.19181/inter.2020.12.4.4
}

\section{Чао Фанг}

Фанг Чао - PhD, научный сотрудник Центра «Смерть и общество», Университет Бата, Великобритания, cf493@bath.ac.uk.

B статье представлено предварительное исследование воздействия COVID-19 на восприятие смерти и переживаний по ее поводу. В рамках этого исследования рассматривается, как социальные нормы и ценности формировались и подвергались изменениям в результате переживаний утраты и горя во время вспышки COVID-19. Изучая соответствующие материалы в средствах массовой информации и в академическом дискурсе, автор критически анализирует проблемы, с которыми сталкиваются те, кто умирает и скорбит во время этой пандемии. В ходе исследования было обнаружено, что как у отдельных людей, так и у коллективов проявляются различные потребности в ответ 
на потери и горе, связанные с COVID-19. В эссе показано, что горе представляет собой процесс осмысления, в котором подчеркивается важность своевременной, целостной и постоянной поддержки, а также социокультурной среды. Также в статье статье исследуются пути дальнейшего развития поддержки в случае утрат.

Ключевые слова: COVID-19; пандемия; тяжелая смерть; горе; поддержка в тяжелой утрате

Дата поступления: 06.10.2020 